\title{
Introduction
}

\section{HUMAN RIGHTS, REFUGEE PROTECTION AND HUMANITARIAN ACTION}

The present issue of the Refugee Survey Quarterly contains the proceedings of the 4th annual humanitarian conference organised by the students and the faculty of Webster University in Geneva in April 1999 on the subject Human Rights, Refugee Protection and Humanitarian Action: Convergence and Co-operation. The earlier conferences had dealt with Geneva and the Challenge of Humanitarian Action of the 1990s in February 1996, Upholding Humanitarian Standards: the Role of the International Community in June 1997 and Internal Conflicts: the Role of Humanitarian Action in April 1998.

The 1990s have witnessed an explosion of forced migration and of massive violations of humanitarian law. At the origin of these developments, or closely connected with them, invariably there have been violations of some of the most fundamental human rights.

As a reaction to this epidemy of political and humanitarian crises, the last ten years have also seen a strong reaffirmation of the most fundamental rights of human persons, and the obligation of states and non-state groups to respect them. The history of the 1990 s will also have been the record of the efforts of the international community, and in particular of the humanitarian organisations broadly defined, to protect and assist the victims of the violations of these rights and to help realise the respect for these obligations and principles.

The objective of the 1999 conference was to highlight the convergence of three major dimensions of international obligations and concern: the protection of the victims of forced displacement, the protection of the victims of war and violence and the upholding of fundamental human rights. International humanitarian law and action, the protection of refugees and of the victims of all forms of forced migration, and international human rights obligations are the three main pillars of the international system of defending the human person. There are the rights of individuals and groups and the obligations to respect them: these rights include those that are most likely to be threatened by perpetrators, oppressive or violent governments or groups; and there are those that imply the right to protection and assistance from the rest of the international community as a whole or from individual states.

The 1999 Webster conference dealt with a highly topical issue that is of great interest to a wide range of people: (1) in the first place, and most directly, the victims or the potential victims living in the many countries 
and regions of the world suffering from different forms of war and violence and from the many forms of political, ethnic, or religious persecution and intolerance, (2) second, the governments and the public in the rest of the world, because these issues have important implications for the quality of world order, and directly or indirectly, also for our own freer and more sheltered lives, and, (3) finally, the topic is of great direct interest for those whose life and work is dedicated to provide protection and assistance, i.e. for the humanitarian workers.

As in the previous Webster conferences, the aim of the organisers was to bring together experts from major governmental and non-governmental organisations and from universities in order to generate a discussion based on their immediate experience and preoccupations. Also, the program of the conference focused again on the role, perception and experience of the major international humanitarian actors, intergovernmental and non-governmental organisations, which are in charge of monitoring the respect of international obligations and which are the principal tools of the international community for carrying out humanitarian actions.

The 1999 conference, as the earlier ones, was held under the auspices of the Geneva Government and benefited from the active support and participation of the United Nations High Commissioner for Refugees, the International Committee of the Red Cross, the Office of the High Commissioner for Human Rights, IOM as well as other major humanitarian organisations.

In fact, the principal international humanitarian organisations have their headquarters in Geneva: the International Committee of the Red Cross and the International Federation of Red Cross and Red Crescent Societies, the UN High Commissioner for Refugees, the UN High Commissioner for Human Rights and the International Organisation for Migration - to name only the most important ones. Other major Genevabased international organisations like the ILO and WHO also have to deal increasingly with the consequences of humanitarian crises. The presence of these organisations in Geneva reflects the recognition and vitality of the "spirit of Geneva" and the humanitarian tradition of the city, as well as the convergence of their tasks and preoccupations and the division of labour among them at the level of their broad mandate and of their daily work. This is complemented and enriched by the presence and work of a broad spectrum of non-governmental organisations.

The conference coincided with the fiftieth anniversary of the Geneva conventions, 1998 marked the fiftieth anniversary of the Universal Declaration of Human Rights and the year 2000 will see the fiftieth anniversary of the creation of UNHCR. This cluster of anniversaries was seen as a symbolic proof that the convergence of the three main pillars of the international protection of the human person is not a recent or accidental phenomenon.

A more tragic reminder of this was another coincidence in time: it was the fact that the conference was held during the war in Kosovo. While the crisis of Kosovo did not appear as such in the program, there was a 
widely-shared conviction among the participants that Kosovo was one of the clearest and most dramatic illustrations of the close interdependence (1) of human rights violations and threats of genocide, (2) of violations of international humanitarian law, and (3) of the intent to achieve "ethnic cleansing" through massive forced migration.

In fact, the topicality of the subject is brought out by: (1) the general awareness and frustration ("the house is burning") of the widespread and systematic violations and disregard for the most basic moral and legal standards and obligations, not only by the powerful, but also by small States and non-State groups, and (2) the widespread impatience in the international community, that we have we have passed the stage of lip-service to principles and obligations: we have to do something.

The example of Kosovo illustrated the reasons for this frustration: (1) exodus, mass flight of refugees did occur (deterrence did not work), (2) it could be reversed only by massive use of force, (3) ethnic cleansing did de facto occur (or is occurring), (4) those whom we wanted to protect did not all turn out to be the innocent, well-intentioned partners, (5) ex-post the international community is spending much more for an uncertain reconstruction and reconciliation than it has been willing to devote ex ante in terms of financial and other resources to prevention and on improving conditions.

\section{Principal Topics}

In the preparation of the program the central idea was that violations of international humanitarian law also represent violations of basic human rights. Similarly, forced migration is, as a rule, the consequence of human rights violations and in many cases also of violations of international humanitarian law. Furthermore, victims of forced migration, refugees or internally displaced people, are often exposed to further actual or potential violations of their basic human rights.

This central issue was considered in a series of general analyses from the perspective of the major categories of rights, actions and organisations involved - UN High Commissioner for Human Rights, International Committee of the Red Cross, UN High Commissioner for Refugees and the International Organisation for Migration.

These broad analyses were complemented by a number of more specific topics dealing in particular with (1) the experience in the field, (2) the need to uphold principles and to increase and strengthen education and dissemination, (3) the situation of children and the need to pay particular attention to their vulnerability, (4) the responsibility of state and penal responsibility of individuals, the weakening of impunity and the future role of the International Criminal Court, (5) the fundamental standards of humanity, (6) how to increase public awareness, (7) implementation, and (8) how to deal with "warring parties" and actual and potential perpetrators. 


\section{Convergence}

In the light of the more general and more specific issues, there was a broad consensus among the speakers with respect to the existence and the nature of the convergence among the three areas or the three pillars of international obligations and actions. The conclusion was clearly: "Yes there is a convergence, and this convergence is centred around the concept of human rights". Also, it is necessary to increase the awareness of this convergence among political leaders, the general public as well as those directly engaged in humanitarian work.

It was also recognised that the concept of convergence and the need for effective co-operation of the efforts to provide effective protection and relief have received a serious boost as a result of both positive and negative developments in the 1990s.

The first, positive factor has been the greater international consensus in the 1990s in condemning, deterring, or even attempting to stop by force if necessary, systematic human rights violations. The new emphasis on human rights, the creation of the Office of the High Commissioner for Human Rights, the importance attributed to the protection of human rights in the reform efforts aimed at making the United Nations a more effective instrument of international action, have all contributed to a more open and less ambiguous attitude towards human rights obligations and potential and actual violations. Real or alleged national or group interests, national sovereignty, political expediency are becoming less and less acceptable arguments to cover up human rights violations or, equally important, to serve as excuses to justify inaction by individual States or the international community as a whole to stop perpetrators from continuing these violations.

The end of Soviet ideology and imperialism has contributed to this positive development, but it has not been the only factor. The fact that Universal Declaration of Human Rights is 50 years old and several of the specific conventions are several decades old, must not lead to the belief that the obligation to respect fundamental human rights was universally accepted, by governments and even by many intellectuals. The actual respect for human rights has not become universal, but today there are much fewer States or respected opinion leaders who will find arguments justifying systematic human rights abuses in the name of revolutionary ideologies or political expediency by other States or groups.

The second, negative and possibly most important, factor is that while "double standards" in the field of human rights have become politically and intellectually less respectable, the actual practice, in particular in conflict areas, has remained or become increasingly worrisome. The scale and the nature of what we call the humanitarian crises of the 1990s, but which in fact are the humanitarian consequences of political crises, and especially of political crises resulting from the breakdown of state structures and of stable political systems, force us to adopt a more global vision. 
Many of these crises have involved actions of so massive and systematic violence, persecution, and violations of human rights, reaching even the stage of genocide, that they have to seen as global phenomena and global violations of basic standards of human conduct. Thus, convergence and co-operation have become issues of great urgency by today because of the increased complexity of crises and situations. This is reinforced by the growth in the number of humanitarian and political actors called upon to deal with the crises and with their consequences.

The question of "convergence and co-operation" was addressed at several levels: (a) the specific rights of individuals, (b) the international obligations of States to respect these rights, (c) the international rights and obligations of the international community to provide protection against the violations of these rights, and (d) what the concept of convergence and co-operation implies at the operational level for the international community in general and for humanitarian workers and humanitarian organisations in particular.

For example, in the context of refugees and forced migration in general, the fact that increasingly HCR also has to work in countries of origin and not only in countries of asylum, and as a result also has to deal with perpetrators, raises important questions of practice and principle with respect to human rights.

Also, the increased emphasis of providing protection to individuals or groups in danger without regard for state sovereignty opens new challenges and opportunities for lawyers, humanitarian workers and political decision-makers alike.

One of the general conclusions of the presentations was the idea that violations of international humanitarian law and forced migration represented violations of basic human rights, of human rights that are also protected under global international instruments and in most of the more serious cases the violations also call for international action. It was clear that the relevance of human rights violations in the context of contemporary wars and refugee crises is not a new discovery. The human rights dimension was always present in the context of international humanitarian law and action as well as with respect to the protection of refugees and other victims of forced migration. It has, however, assumed a new importance under current circumstances and there is no doubt that the new "human rights awareness and activism" of the international community as a whole comes as a welcome re-enforcement of both the principles and of the action of the other organisations concerned.

\section{Specificity}

At the same time, however, there was also broad agreement among the speakers that it is equally important not to lose sight of the specificity of the various obligations, mandates and actions. The reason for this specificity has to do with three sets of factors: (1) the differences in the nature 
of the obligations of the States, (2) the nature of the rights and duties of the members of the international community individually and collectively to deal with violations, and (3) the specific tasks and responsibilities of the various organisations and their individual representatives in the field.

Trying to amalgamate the various rights and obligations would lead to confusion both at the level of principles and of action, and would weaken rather than strengthen the protection of individuals and groups.

The necessary recognition of convergence must not be used as a pretext for confusing or eliminating the equally important specificity of rules, mandates and action. This specificity and division of labour are important among major areas and organisations, as well as between governmental and non-governmental organisations, between advocacy and project NGOs, etc.

One of the underlying themes of the conference was the complexity of the situation with respect to rights and the extent of violations, the protection of victims, the willingness or the ability of the international community to enforce rules, to deter, to stop and to punish grave violations, by States, other groups as well as by individuals.

This complexity in the world around us, where both governments and non-state groups have shown extensive violence and complete disregard for moral and legal respect for foreigners and for fellow citizens, calls for vigilance, imagination and co-operation in both discouraging these violations and in helping and protecting the actual and potential victims of these acts.

It is clear that there is and should remain a useful division of labour rather than a rigid hierarchy at the level of responses, actions and principles. The multiplicity and the occasional overlapping of rules and actors should be less a source of confusion (or even rivalry among humanitarian actors) than a source of strength that helps avoid potential loopholes and serves as a deterrent to potential perpetrators.

Also, the question: what should receive more emphasis, a narrow, technical definition or a broad general definition of rights and of potential violations, should not, cannot receive a definitive, unambiguous answer. Establishing an abstract hierarchy of rights in terms of enforceability or in terms of seriousness of violations is not the answer.

\section{Outlook}

We have to recognise, the international community has to continue to recognise the existence and the need for different categories of responsibilities and of different types of action.

Individual actors may have to face difficult questions of practice and principle of the following type: what should be our hierarchy of objectives, immediate assistance to the victims or condemnation without compromise, do we have to co-operate with the perpetrators and under what conditions, do we have to choose between advocacy and assistance? 
Because of the diversity and complementarity of norms and actors, the international community as a whole is not subject to the constraints of the individual organisations. Thus, the diversity of rules and instruments is a source of strength rather than a weakness.

The general lesson of the conference, and in fact of recent years, for the international organisations and humanitarian actors, for the general public, for the international community, and for the actual or potential perpetrators can be summed up in the following brief statement: the realisation of the nature and limits of the convergence and the division of tasks, and the implementation of effective co-operation can lead to the strengthening of all three pillars. For all of us this can be a source of cautious optimism for the future.

Otto Hieronymi

Head, Programme of International Relations and of Migration and Refugee Studies, Webster University, Geneva, Guest-Editor 